\title{
Technoprener di Politeknik Negeri Bengkalis
}

\author{
Suharyono*1, Dwi Astuti2 ${ }^{2}$, Marhadi Sastra3 ${ }^{3}$ Lidya Wati ${ }^{4}$ \\ ${ }_{1}$ Program Studi D4 Akuntansi Keuangan Publik, Politeknik Negeri Bengkalis \\ 2Program Studi D3 Administrasi Bisnis, Politeknik Negeri Bengkalis \\ ${ }^{3}$ Program Studi D3 Teknik Sipil, Politeknik Negeri Bengkalis \\ ${ }^{4}$ Program Studi D4 Rekayasa Perangkat Lunak, Politeknik Negeri Bengkalis

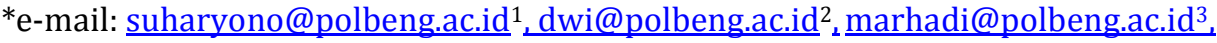 \\ lidyawati@polbeng.ac.id ${ }^{4}$
}

\begin{abstract}
The Entrepreneurship Development Program aims to implement entrepreneurial practices and civilize entrepreneurship for Bengkalis State Polytechnic students and graduates that are in line with the field of academic science in order to realize technopreneur. The target of this activity every year is to produce five or more technopreneurs who have the mental and entrepreneurial character that is intelligent, strong determination, discipline, hard-working, confident, risk taker, never give up, honest, creative, innovative, and sincere. To realize this target, the team has conducted an information dissemination on the Entrepreneurship Development Program to students and graduates. Then proceed with the selective recruitment of tenant participants. Tenant participants who pass the selection will get entrepreneurship training. In addition, participants will also take part in internships in businesses that are in accordance with their business ideas or conduct benchmarking visits. During the Entrepreneurship Development Program activities, the team will provide guidance, assistance and or consultancy to tenants to be able to produce prospective, innovative and economical academic-based businesses.
\end{abstract}

Keywords: Programs, Development, Entrepreneurship, Technopreneur, Tenant.

\begin{abstract}
Abstrak
Program Pengembangan Kewirausahaan (PPK) ini bertujuan untuk mengimplementasikan praktikpraktik berwirausaha dan membudayakan wirausaha bagi mahasiswa dan alumni Politeknik Negeri Bengkalis yang sejalan dengan bidang ilmu akademik demi mewujudkan technopreneur. Target dari kegiatan ini setiap tahunnya adalah dihasilkannya lima atau lebih technopreneur yang memiliki mental dan karakter entrepreneur yaitu cerdas, tekad yang kuat, disiplin, pekerja keras, percaya diri, risk taker, pantang menyerah, jujur, kreatif, inovatif, dan ikhlas. Untuk merealisasikan target tersebut, tim telah melakukan sosialisasi tentang program PPK kepada mahasiswa dan alumni. Kemudian dilanjutkan dengan rekrutmen peserta tenant secara selektif. Peserta tenant yang lulus seleksi akan mendapatkan pelatihan kewirausahaan. Selain itu, peserta juga akan mengikuti magang pada usaha-usaha yang sesuai dengan gagasan usahanya atau melakukan kunjungan benchmarking. Selama kegiatan PPK, tim akan melakukan bimbingan, pendampingan, dan atau konsultansi kepada tenant untuk dapat menghasilkan usaha berbasis bidang ilmu akademik yang prospektif, inovatif dan ekonomis.
\end{abstract}

Kata kunci: Program, Pengembangan, Kewirausahaan, Technopreneur, Tenant.

\section{PENDAHULUAN}

Politeknik Negeri Bengkalis (Polbeng) telah merealisasikan beberapa kebijakan dan program untuk menumbuhkembangkan jiwa kewirausahaan dan meningkatkan aktivitas kewirausahaan, salah satunya melalui penerapan mata kuliah kewirausahaan di seluruh program studi yang ada di Polbeng. Selain itu, agar program kewirausahaan dapat berjalan secara berkesinambungan, Polbeng saat ini sudah memiliki unit khusus pengembangan kewirausahaan atau disebut dengan Unit Kewirausahaan dan juga telah mendirikan Inkubator Bisnis Teknologi. Program-program yang telah dijalankan oleh Unit Kewirausahaan Polbeng, antara lain: kegiatan pelatihan kewirausahaan bagi mahasiswa/alumni, Program Mahasiswa Wirausaha (PMW), Program Kreativitas Mahasiswa bidang Kewirausahaan (PKM-K), dan Kompetisi Bisnis Mahasiswa Indonesia (KBMI). 
Berdasarkan data yang diperoleh dari Unit Kemahasiswaan Polbeng, untuk PMW tahun 2018, ada 6 usulan usaha yang berhasil lolos dan didanai dari total 10 usulan yang diajukan mahasiswa. Nama-nama usulan yang masuk dan didanai yaitu:

1. Egg Roll Aneka Isi oleh Dhery Muammar mahasiswa Teknik Sipil;

2. Handicraft House oleh Fitri mahasiswa Administrasi Bisnis Internasional;

3. Print 123 oleh Rio Chandra mahasiswa Teknik Informatika;

4. Jasa Desain Grafis Berbasis Web oleh Ali Imran mahasiswa Teknik Informatika;

5. Egg Roll Abad-21 oleh Bobby Afrianda mahasiswa Teknik Elektro; dan

6. Warung Seblak Loba Rasa oleh Dea Yulianti mahasiswa Akuntansi Keuangan Publik.

Penyebab rendahnya usulan yang diterima adalah kurangnya kreativitas dan inovasi yang berbasis bidang ilmu akademik mereka. Jika dicermati, jenis usaha yang diusulkan dan dijalankan mahasiswa, pada umumnya usaha mereka belum mendasarkan pada ilmu pengetahuan akademik mereka. Seperti mahasiswa dari Prodi Teknik Sipil dan Elektro, yang mengusulkan usaha dibidang kuliner, sedangkan mahasiswa dari Prodi Adm Bisnis Internasional mengusulkan usaha handicraft.

Begitu juga usulan PKM-K yang diajukan mahasiswa belum berhasil memperoleh pendanaan. Namun pada tahun 2017 ada 8 usulan PKM bidang lainnya yang berhasil lolos, yaitu: 1. PKMKC TI-SADIS (Teknologi IoT untuk Smart Absensi Digital Terintegrasi) di ketuai oleh Roiboslin Gultom;

2. PKMKC Sistem Pakar Diagnosis Penyakit ISPA Berbasis Speech Recognition Menggunakan Metode Naive Bayes Classifier (Sipakde) dengan ketua Mariam Marlina;

3. PKMKC Lampu Navigasi Jaring Nelayan Menggunakan Energi Alternatif Air Laut, dengan ketua M. Affandi;

4. PKMKC He's Kemocy (Helmet SmartKey Motorcycle) dengan ketua Susi Rama Nuryanti;

5. PKMT Penerapan Alat Pemarut Sagu Portable Pada Usaha Mie Sagu Barokah Bengkalis dengan ketua Audal Amri;

6. PKMKC (HHO Generator) Alat Elektrolisis Air Menjadi Gas Hidrogen Sebagai Bahan Bakar Alternatif Ramah Lingkungan dengan ketua Suherman;

7. PKMPE Habis Manis Sepah Di Manfaatkan Ampas Tebu digunakan sebagai Bahan Alternatif Penguat Kontruksi Kapal dengan ketua Siti Aisyah; dan

8. PKMT Alat Pengayak Tepung Sagu Untuk Meningkatkan Kapasitas Produksi Usaha Mie Sagu Barokah Bengkalis dengan ketua Gaporurahim.

Untuk usulan program KBMI, dari tahun 2017 sd 2019 menunjukkan peningkatan. Pada tahun 2019, dari 25 usulan yang diajukan, 4 usulan berhasil memperoleh pendanaan. Usulan yang memperoleh pendanaan disajikan pada Tabel 1.

Tabel 1. Penerima Pendanaan KBMI 2017 s.d. 2019

\begin{tabular}{llll}
\hline No & Tahun & \multicolumn{1}{c}{ Judul Usulan } \\
\hline 1. & 2017 & a. Pomade Terubuk & \multicolumn{1}{c}{ Program Studi } \\
2. & 2018 & b. Mug Advertising & Teknik Informatika \\
& & c. Tanjak & Rekayasa Perangkat Lunak \\
3. & 2019 & d. Q-Mou Healthy Factory & Teknik Informatika \\
& & e. DUE-IT (Doa, Usaha, Etos Ikhtiar dan & Adm Bisnis Internasional \\
& & Tawakal) & Adm Bisnis \\
& & f. Lempernas (Lembaga Perjajanan Nasional) & Akuntansi Keuangan Publik \\
& & g. Edam Burger & Akuntansi Keuangan Publik \\
\hline
\end{tabular}

Lapangan usaha, mudah untuk exit dan entry. Perkembangan usaha mikro, mempunyai peran yang cukup tinggi bagi perekenomian Indonesia (Masnita dkk, 2020). Hidup ini adalah pilihan. Mahasiswa telah diberikan kesempatan untuk membuat pilihan atas program kewirausahaan yang ditawarkan. Menurut Kasali (2002) driver adalah sebuah sikap hidup yang membedakan dirinya dengan passanger, anda tinggal memilih ingin duduk manis menjadi 
penumpang dibelakang atau mengambil resiko sebagai driver didepan. Menurut Sumarno \& Suarman (2017), jumlah mahasiswa yang membuat renacana bisnisnya sesuai ilmu akademiknya, rata-rata hanya 5\%. Bila mengacu pada ungkapan Direktorat Akademik Ditjen Dikti Kemdiknas (2008), bahwa technopreneur mendasarkan ke-enterpreneuran-nya berdasarkan keahlian yang berbasis pendidikan dan pelatihan yang didapatkannya di bangku perkuliahan ataupun percobaan pribadi, maka dapat dikatakan bahwa kewirausahaan mahasiswa di Polbeng belum berorientasi technopreneur. Menurut Suparno, Hermawan, dan Syuaib (2008), technopreneur mampu menggabungkan antara ilmu pengetahuan yang dimiliki melalui kreasi/ide produk yang diciptakan dengan kemampuan berwirausaha melalui penjualan produk yang dihasilkan di pasar. Lebih lanjut mereka mengungkapkan bahwa pengembangan berbagai pusat inovasi dan inkubator bisnis dalam bidang teknologi di beberapa perguruan tinggi dan lembaga riset merupakan upaya yang positif untuk membangun technopreneurhsip di Indonesia. Hal itu sejalan dengan Handrimurthahjo (2013), yang berpendapat bahwa Indonesia memiliki peluang mengembangkan technopreneurship untuk menciptakan nilai tambah khususnya bagi produkproduk pertanian, kehutanan, peternakan, dan perikanan. Pentingnya technopreneurship bagi kemajuan/masa depan bangsa/masyarakat, maka menuntut diperlukannya program pengembangan kewirausahaan mahasiswa yang berorientasi technopreneurship melalui PPK.

Permasalahan kewirausahaan di Politeknik Negeri Bengkalis adalah:

1. Terbatasnya dan minimnya anggaran PMW yang tersedia;

2. Bidang usaha yang diusulkan atau dijalankan belum sesuai dengan kompetensi atau bidang akademik mahasiswa; dan

3. Minimnya unsur kreativitas dan inovasi atas sebagian produk yang dihasilkan mahasiswa.

Program Pengembangan Kewirausahaan (PPK) ini bertujuan untuk mengimplementasikan praktik-praktik berwirausaha dan membudayakan wirausaha bagi mahasiswa dan alumni Politeknik Negeri Bengkalis yang sejalan dengan bidang ilmu akademik demi mewujudkan technopreneur. Target dari kegiatan ini setiap tahunnya adalah dihasilkannya lima atau lebih technopreneur yang memiliki mental dan karakter entrepreneur yaitu cerdas, tekad yang kuat, disiplin, pekerja keras, percaya diri, risk taker, pantang menyerah, jujur, kreatif, inovatif, dan ikhlas.

Untuk merealisasikan target tersebut, tim akan melakukan sosialisasi tentang program PPK kepada mahasiswa dan alumni. Kemudian dilanjutkan dengan rekrutmen peserta tenant secara selektif. Peserta tenant yang lulus seleksi akan mendapatkan pelatihan kewirausahaan. Selain itu, peserta juga akan mengikuti magang pada usaha-usaha yang sesuai dengan gagasan usahanya atau melakukan kunjungan benchmarking. Selama kegiatan PPK, tim akan melakukan bimbingan, pendampingan, dan atau konsultansi kepada tenant untuk dapat menghasilkan usaha berbasis bidang ilmu akademik yang prospektif, inovatif dan ekonomis.

\section{METODE}

Program Pengembangan Kewirausahaan (PPK) Polbeng Technopreneur merupakan kegiatan pengabdian multi tahun yang didanai DRPM Kemenristek/BRIN mulai tahun 2020 sampai 2022. PPK Polbeng Technopreneur memiliki tujuan untuk mewujudkan technopreneur atau wirausaha baru yang mandiri dari kalangan mahasiswa dan alumni Politeknik Negeri Bengkalis. Tempat kegiatan pengabdian kepada masyarakat dilaksanakan di Gedung Sekretariat PPK Politeknik Negeri Bengkalis, Jl. Bathin Alam, Desa Sungai Alam, Kabupaten Bengkalis, Provinsi Riau.

Tahapan dalam pelaksanaan kegiatan pengabdian kepada masyarakat PPK Polbeng Technopreneur, yaitu:

1. Sosialisasi;

2. Seleksi tenant/penilaian proposal usaha tenant;

3. Pelatihan kewirausahaan; 
4. Magang/benchmarking;

5. Pelaksanaan usaha tenant (starting-up business);

6. Bimbingan/konsultansi; dan

7. Monitoring dan evaluasi kinerja tenant.

Pada bagian metode penerapan, uraikanlah dengan jelas dan padat metode yang digunakan untuk mencapai tujuan yang telah dicanangkan dalam kegiatan pengabdian. Hasil pengabdian adalah menghasilkan 5 wirausaha baru yang mandiri. Alat ukur yang dipakai untuk menilai usaha tenant yaitu rasio keuangan dan analisis break even point. Tingkat ketercapaian pengabdian ini juga dapat dilihat dari sisi, yaitu:

1. Kemampuan tenant dalam memproses pesanan pelanggan;

2. Peningkatan kompetensi tenant dalam mengelola usaha;

3. Peningkatan kompetensi tenant dalam bidang produksi;

4. Peningkatan kompetensi tenant dalam memasarkan produk; dan

5. Peningkatan kompetensi tenant dalam mengelola keuangan usaha.

\section{HASIL DAN PEMBAHASAN}

\section{Sosialisasi}

Sosialisasi diperlukan untuk memperkenalkan program PPK kepada mahasiswa dan alumni Politeknik Negeri Bengkalis. PPK Polbeng Technopreneur merupakan program pertama yang melibatkan mahasiswa dan alumni dalam berwirausaha. Sosialisasi kegiatan PPK kepada mahasiswa dan alumni dilakukan dengan menyebarkan panduan dan jadwal rekrutmen melalui mading jurusan/prodi, melalui dosen pengampu mata kuliah kewirausahaan, dosen wali, dosen pembimbing PMW, dosen pembimbing PKM, dosen pembimbing KBMI, pengurus PMW dan whatsapp group alumni.

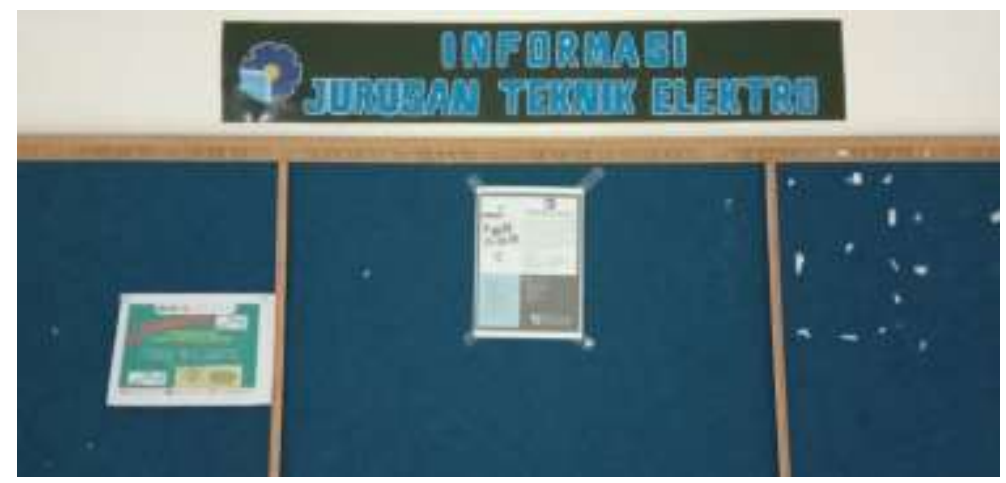

Gambar 1. Sosialisasi Melalui Mading

\section{Seleksi Tenant}

Target dari kegiatan ini setiap tahunnya adalah dihasilkannya lima atau lebih technopreneur yang memiliki mental dan karakter entrepreneur yaitu cerdas, tekad yang kuat, disiplin, pekerja keras, percaya diri, risk taker, pantang menyerah, jujur, kreatif, inovatif, dan ikhlas. Seleksi calon tenant dimulai dengan menerima pendaftaran melalui daring. Peserta calon tenant akan diseleksi berdasarkan rencana usaha atau usaha yang telah dilakukan, motivasi calon tenant, dan kesanggupan calon tenant mengikuti kegiatan PPK. Seleksi dilakukan untuk menentukan 20 orang mahasiswa dan alumni sebagai tenant PPK. Daftar tenant dapat dilihat pada Tabel 2. 
Tabel 2. Daftar Tenant PPK Tahun 2020

\begin{tabular}{lllll}
\hline No & \multicolumn{1}{c}{ Nama } & \multicolumn{1}{c}{ Prodi } & \multicolumn{1}{c}{ Status } & \multicolumn{1}{c}{ Bidang Usaha } \\
\hline 1 & Suherman, S.Tr.T & D4 Mesin Produksi dan Perawatan & Alumni & Bengkel Las \\
2 & Mohd. Azuar & D4 Mesin Produksi dan Perawatan & Mahasiswa & Bengkel Las \\
3 & Eko Ade Atma, A.Md & D3 Teknik Informatika & Alumni & Web Desain \\
4 & Ali Imran & D3 Teknik Informatika & Mahasiswa & Kursus \\
5 & Putri Wulandari & D3 Administrasi Bisnis & Alumni & Kursus \\
6 & Faisal Hasby Sadiq & D4 Teknik Listrik & Mahasiswa & Service AC \\
7 & Karina Krisnanda & D4 Akuntansi Keuangan Publik & Mahasiswa & Kuliner \\
8 & Nurlaili & D4 Akuntansi Keuangan Publik & Mahasiswa & Kuliner \\
9 & Juliyana & D4 Akuntansi Keuangan Publik & Mahasiswa & Kuliner \\
10 & Bayu Prananda & D3 Teknik Sipil & Mahasiswa & Fotocopy \\
11 & Khoirun Nizam & D4 Akuntansi Keuangan Publik & Mahasiswa & Print \\
12 & Anggi Hardianto & D4 Teknik Listrik & Mahasiswa & Content Creator \\
13 & Randa Kurnialis & D4 Rekayasa Perangkat Lunak & Mahasiswa & Content Creator \\
14 & Erpan Syahrizan & D4 Adm Bisnis Internasional & Mahasiswa & Content Creator \\
15 & Rama Mahendra & D4 Akuntansi Keuangan Publik & Mahasiswa & Content Creator \\
16 & Agus Setiawan & D4 Akuntansi Keuangan Publik & Mahasiswa & Content Creator \\
17 & Muhaimi N. Lathif & D3 Teknik Informatika & Alumni & Content Creator \\
18 & Afis & D3 Administrasi Bisnis & Mahasiswa & EO \\
19 & Rahmad Aldi & D3 Administrasi Bisnis & Mahasiswa & EO \\
20 & Intan Fajrina Lestari & D3 Administrasi Bisnis & Mahasiswa & EO \\
\hline
\end{tabular}

\section{Pelatihan Kewirausahaan}

Pelatihan kewirausahaan dilakukan pada tahap awal setelah diperoleh tenant peserta PPK. Pelatihan ini dimaksudkan untuk memberikan bekal dan atau meningkatkan kemampuan kreativitas menciptakan usaha berbasis ilmu pengetahuan akademiknya serta kemampuan dalam menerapkan hasil kreativitasnya dalam usaha yang berorientasi profit/komersial (berinovasi) secara profesional. Kemampuan berinovasi mencakup kemampuan dalam: mencari dan mendapatkan informasi peluang usaha, memperhitungkan dan menghadapi risiko, mengelola sumber daya (manusia, material, dan keuangan), memasarkan produk, menghadapi persaingan, menyusun laporan keuangan, dan mengembangkan usaha. Selain itu, kunci sukses kebehasilan berwirausaha terletak dalam memperoleh dan mengelola informasi (Nilma, 2020). Menurut Putri (2017) pelatihan mampu meningkatkan $70 \%$ aspek pengetahuan dan keterampilan.

\section{Magang/Benchmarking}

Untuk melengkapi kemampuan teoritis dan praktis yang diperoleh dari pelatihan, tenant akan ikut serta dalam kegiatan magang usaha atau melakukan kunjungan benchmarking. Kegiatan ini diutamakan pada usaha yang sejenis/sesuai dengan rencana usaha dalam proposal usaha tenant. Magang dan benchmarking dilaksanakan mulai tanggal 15 sampai 19 Juli 2020. Adapun perusahaan yang menjadi target pelaksanaan magang dan benchmarking, yaitu: Degenius, Rulika Teknik, dan Astragraphia.

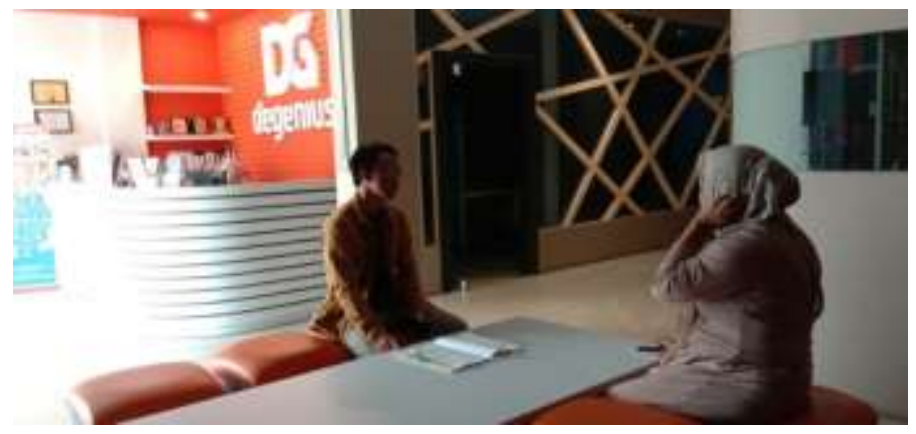

Gambar 2. Benchmarking di Degenius Pekanbaru 


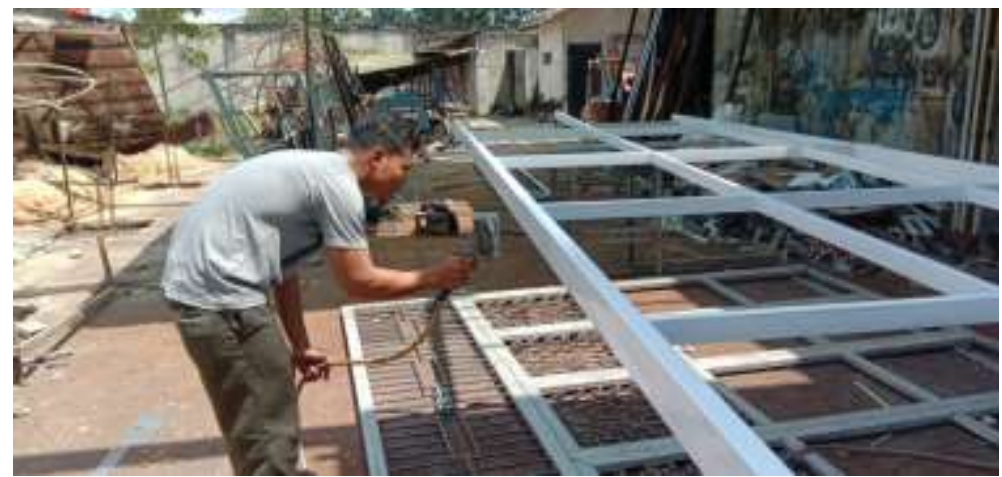

Gambar 3. Magang di Rulika Teknik Pekanbaru

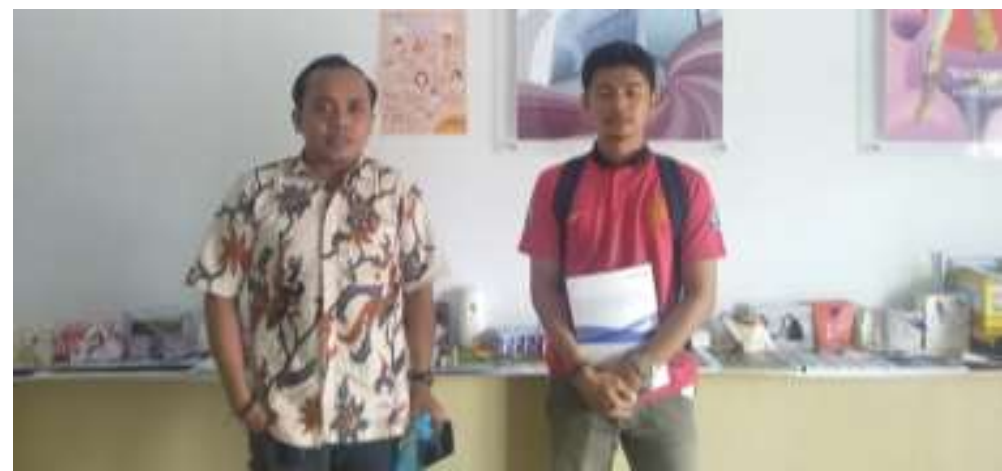

Gambar 4. Benchmarking di Astragraphia Fuji Xerox Pekanbaru

\section{Pelaksanaan Usaha Tenant}

Pelaksanaan usaha tenant telah dimulai sejak 20 Juli 2020. Dengan kompetensi yang dimiliki oleh tenant, di dukung dengan pelatihan, magang dan benchmarking yang telah dilakukan, target untuk menghasilkan 5 wirausaha baru yang mandiri diharapkan dapat terwujud. Sebagai bentuk tanggungjawab tenant, beberapa pesanan pelanggan telah diselesaikan oleh tenant, seperti:

a. Karikatur cenderamata yang dikerjakan oleh tenant web desain;

Terima Kasih atas ikhtasmu Selama is Tahun

Membangun Pendidikan di Politelinik Negeri Bengkalis

\section{Ir. Muhamad Milchan, MT}

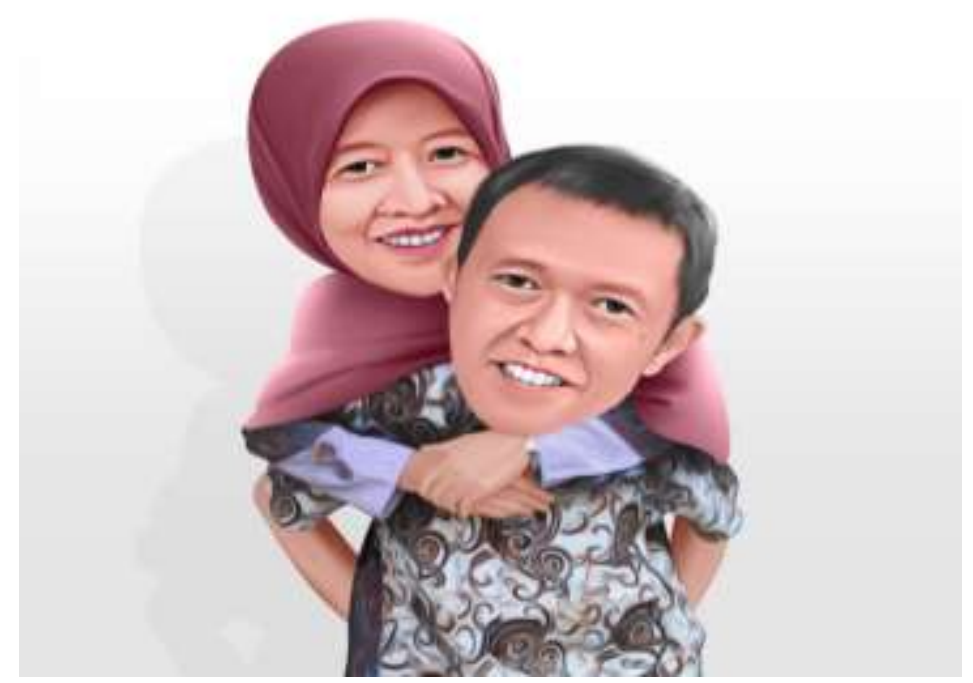

Gambar 5. Cenderamata Karikatur Direktur Polbeng Masa Jabatan 2005-2020 
b. Pembuatan gerobak yang dikerjakan oleh tenant bengkel las Ferolas;

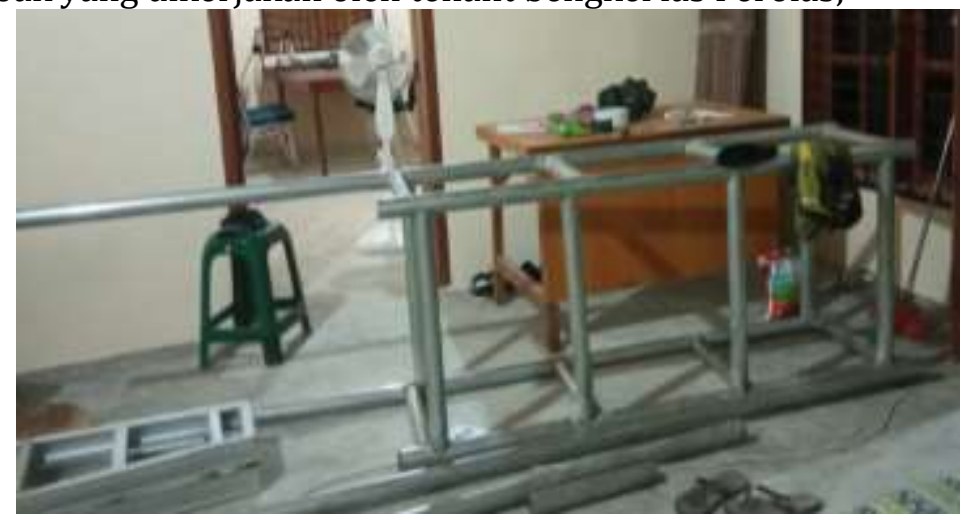

Gambar 6. Pengelasan Gerobak

c. Pembuatan konten untuk youtube channel;

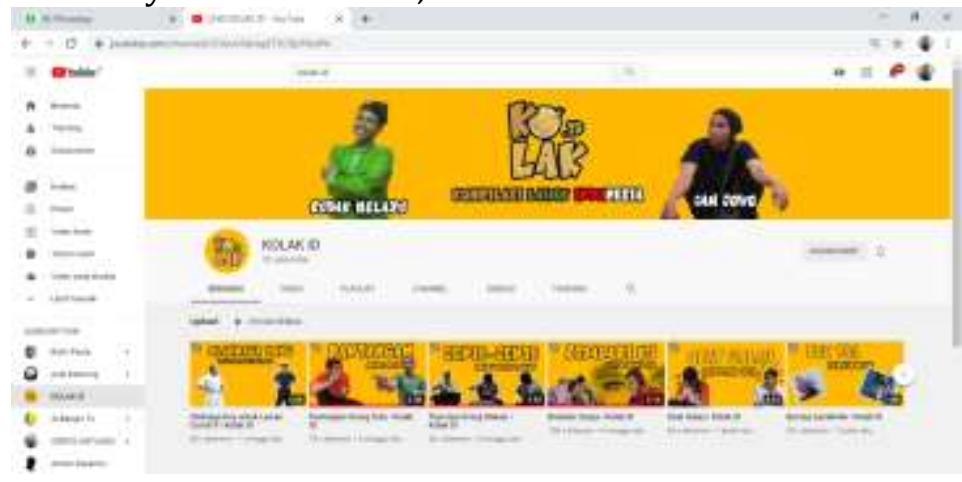

Gambar 7. Content Creator Kolak.id

d. Cetak dan fotocopy skripsi mahasiswa; dan

e. Pembuatan pesanan edam burger.

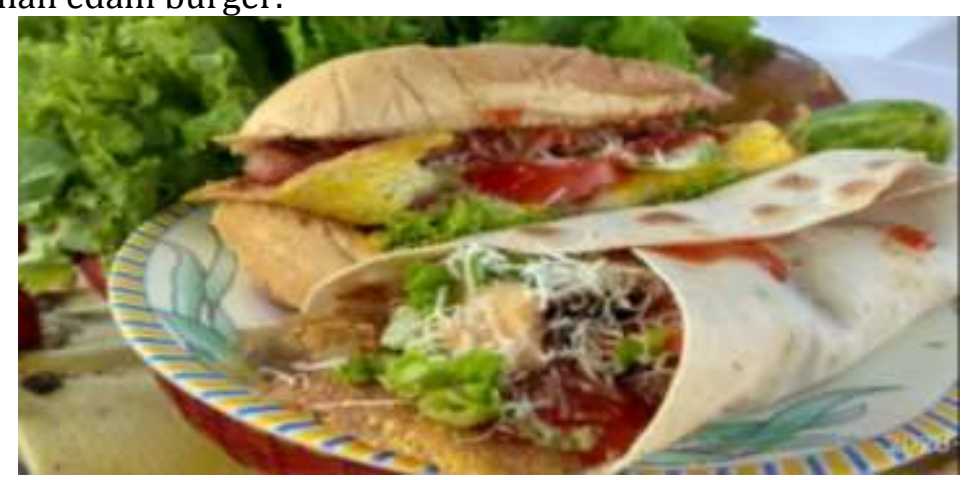

Gambar 8. Kebab dan Burger

\section{KESIMPULAN}

Program Pengembangan Kewirausahaan (PPK) memiliki target yaitu menghasilkannya lima atau lebih technopreneur yang memiliki mental dan karakter entrepreneur yaitu cerdas, tekad yang kuat, disiplin, pekerja keras, percaya diri, risk taker, pantang menyerah, jujur, kreatif, inovatif, dan ikhlas. Melalui seleksi yang telah dilakukan, tim PPK telah menetapkan 20 orang mahasiswa dan alumni sebagai tenant PPK. Fasilitas yang diperoleh tenant, yaitu pelatihan kewirausahaan, magang di perusahaan yang diinginkan, benchmarking, pendampingan, serta fasilitas peralatan dan tempat berwirausaha. Sebagai wujud tanggungjawab tenant, beberapa pesanan pelanggan telah selesai dikerjakan oleh tenant. 


\section{UCAPAN TERIMA KASIH}

Penulis mengucapkan terima kasih kepada DRPM Kemenristek/BRIN dan Politeknik Negeri Bengkalis yang telah memberi dukungan financial terhadap pengabdian ini.

\section{DAFTAR PUSTAKA}

Direktorat Akademik Ditjen Dikti Kemdiknas. (2008). Technopreneurship. www.undana.ac.id/index.php?option=com...view...pdf. Diakses pada 2 Februari 2020.

Handrimurtjahjo, A. D. (2016). Model Pembelajaran Kewirausahaan di Perguruan Tinggi. Jurnal Universitas Paramadina, 10(2), 729-755.

Kodrat, David S. dan Christina, Wina. (2015). Entrepreneurship Sebuah Ilmu. Jakarta, Erlangga.

Kasali, Rhenald. (2002). Self Driving-Menjadi Driver atau Passangers?. Mizan, Jakarta.

Masnita, Y. (2020). Peningkatan Daya Saing Usaha Mikro (UMi) Melalui Keuangan Inklusi. Dinamisia: Jurnal Pengabdian Kepada Masyarakat, 4(2, Juni).

Nilma, N., Nuzulah, R., \& Mardika, P. D. (2020). Penyuluhan Tentang Kewirausahaan melalui Media Sosial Kepada Ibu-Ibu PKK di Wilayah Kelurahan Abadijaya, Sukamaja, Depok. Jurnal PkM Pengabdian kepada Masyarakat, 3(1), 101-106.

Putri, D. L., Wardi, J., \& Khairani, Z. (2017). Pelatihan Kewirausahaan Ibu-Ibu Rumah Tangga pada Kelurahan Sri Meranti Kecamatan Rumbai Pesisir Kota Pekanbaru. Dinamisia: Jurnal Pengabdian Kepada Masyarakat, 1(1), 145-151.

Sumarno dkk. (2018). Desain Pendidikan Kewirausahaan Mahasiswa Berbasis Technopreneurship. Jurnal Ekonomi Pendidikan dan Kewirausahaan, Vol. 6 No. 2 hh. 171-186.

Sumarno, Suarman, dan Gani Haryana. (2017). Model Pendidikan Kewirausahaan Mahasiswa Berbasis Technopreneurship. LPPM Universitas Riau.

Sumarno \& Suarman. (2017). Development of Technopreneurship-based Entrepreneurship Education for Students at Universitas Riau, Indonesia. International Journal of Economic Research, Volume 14 Number 12, 2017. pp. 65-74.

Suparno, Ono. Hermawan, Aji. dan Syuaib, M. Faiz. (2008). Technopreneur. Recognition and Mentoring Program-Institut Pertanian Bogor (RAMP-IPB). http://ono.suparno.staff.ipb.ac.id/articles/technopreneurship-2/. 